\title{
New evidence of the Vuoksi River origin by geodynamic cataclysm
}

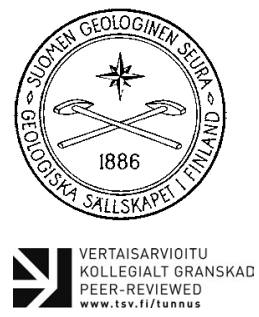

\author{
Dmitry A. Subetto ${ }^{1,2,3}{ }^{*}$, Sergey V. Shvarev ${ }^{4,5}$, Andrey A. \\ Nikonov ${ }^{5}$, Natalya E. Zaretskaya ${ }^{6}$, Anton V. Poleshchuk ${ }^{5,6}$ \\ and MaKsim S. PotaKhin ${ }^{\mathrm{I}}$
}

${ }^{1}$ Northern Water Problems Institute, Karelian Research Centre of Russian Academy of Sciences, Alexander Nevsky pr. 50, Petrozavodsk, 185030, Russia

${ }^{2}$ Herzen State Pedagogical University of Russia, emb. Moika 48, Saint-Petersburg, 191186, Russia

${ }^{3}$ Immanuel Kant Baltic Federal University, A. Nevsky st. 14, Kaliningrad, 236016, Russia

${ }^{4}$ Institute of Geography, Russian Academy of Sciences, Staromonetny lane 29, Moscow, 119017, Russia

${ }^{5}$ Schmidt Institute of the Physics of the Earth, Russian Academy of Sciences, Bolshaya Gruzinskaya str., 10-1, Moscow, 123242, Russia

${ }^{6}$ Geological Institute, Russian Academy of Sciences, Pyzhevsky lane 7, Moscow, 119017, Russia

\section{Abstract}

The territory of investigations is located in the SE periphery of the Fennoscandian Shield. It served as an arena of periodic significant restructuring of the hydrographic network associated with the filling and discharge of large late-glacial and Holocene basins during the degradation of the Scandinavian ice sheet and in postglacial time. One such restructuring is a sudden change of the Saimaa Lake direction of flow in the middle Holocene from the west to south to the Lake Ladoga basin via the drainage hollow, inherited by modern Vuoksi River valley. Origin of the Vuoksi River is associated with the catastrophic water breakthrough of the Saimaa Lake across the marginal ridge Salpausselkä I of about 5.7 cal. kyr BP. This event usually connects with water accumulation and overflow due to non-uniform post-glacial uplift according to modern concepts. The authors propose a great earthquake as the immediate cause of the break waters of Saimaa Lake. This suggestion is based on the study of specific deformations of the rocky riverbed in the area of breakthrough and of the loose deposits in the banks of the Vuoksi River valley downstream. Open cracks and horizontally displaced rock blocks were discovered in the area of the former rapids near town Imatra. Their systematic displacements on the both sides of the rocky gorge indicate the shear kinematics of fault zone. Different types of deformations had occurred in loose sediments of the low terraces (3-4 m) in the Vuoksi River valley and 20-30 km below the headwaters. In three studied stratigraphic sections the three cardinal different types of deformations 
were discovered: 1) normal fault with vertical displacements, 2) tectonic inclination, and 3) traces of catastrophic mudflow. The time diapason of the terrace forming (and of the corresponding deformations) is determined of 8.3 to $1.8 \mathrm{cal}$. kyr BP (by the ages of adjacent terrace levels), which corresponds to the origination time of the Vuoksi River.

The earthquake, which presumably was a trigger for the formation of the Vuoksi River, was generated by the activation of ancient fault zone, manifested in the crystalline foundation. Periodic post-glacial tectonic activity of this zone is revealed in traces of strong seismic events both in the bedrock (initial emergence of the gorge, its renewal during the breakthrough), and in loose deposits (deformations in different levels of terraces).

Keywords: Holocene, Fennoscandian shield, paleoearthquake, seismic deformations, Saimaa Lake, catastrophic breakthrough

*Corresponding author (e-mail: dsubetto@nwpi.krc.karelia.ru)

Editorial handling: Pertti Sarala (pertti.sarala@gtk.fi)

\section{Introduction}

Numerous traces of strong earthquakes were discovered and studied in the recent decades in the different parts of Fennoscandia, from the west - in Sweden, Norway, and Finland (Kujansuu, 1964; Lundqvist \& Lagerbäck, 1976; Olesen et al., 1992; Sjöberg, 1994; Bungum \& Lindholm, 1997; Kuivamäki et al., 1998; Dehls et al., 2000; Mörner, 2003; Lagerbäck \& Sundh, 2008; Kukkonen et al., 2011), to the east - in Russia (Lukashov, 1995, 2004; Zykov, 2001; Nikonov et al., 2001; Nikonov, 2002, 2003, 2007, 2008; Nikonov \& Miidel, 2003; Nikolaeva, 2008; Nikolaeva et al., 2016; Nikonov \& Zykov, 2017).

A spot with pronounced seismic deformations was discovered earlier in the basin of the Vuoksi River (Nikonov et al., 2011, 2014). Three seismic events, which happened during the Holocene, were identified at the location. This site of deformations is associated with activation of the ancient "Vuoksi Fault Zone" (VFZ), extending over several tens of kilometres from the Finnish border to the SE direction as a pattern of several subparallel branches.
The SE periphery of the Fennoscandian Shield was an arena of periodic significant restructuring of the hydrographic network associated with the filling and discharge of large late-glacial and Holocene basins during the degradation of the Scandinavian ice sheet and in the postglacial time. One such restructuring is a sudden change in the middle Holocene of the direction of flow of the Lake Saimaa from the west to south to the Ladoga Lake basin via the drainage hollow, inherited by the modern Vuoksi River valley. Abrupt alteration of the flow of the lake basin and the earlier changes in flow direction which occurred here were associated with the postglacial isostatic uplift, numerous transgression stages of the Lake Saimaa basin, and final overflow about 5700 cal. years BP (Saarnisto, 1970). Detailed reconstruction of this process on the basis of intensive general uplift of the territory during the Holocene is shown by Pajunen (2004, 2005).

It was suggested early and published recently by Nikonov (2017) that earthquake was the reason for the breakthrough of the Lake Saimaa to the valley of the Vuoksi River, because its riverbed inherits 
this activated fault zone. A strong seismic event was considered to be the trigger that led to the crushing of the substrate (forming the gap) and/or to the overflow of the waters through the Salpausselkä I marginal ridge barrier.

In this study, the authors led the search for evidence of temporal and spatial connections between the Lake Saimaa overflow and strong earthquakes in the middle of Holocene. The study consists of two main parts. The first part includes an analysis of structural and tectonic features of the study area for the reasonableness of the hypothesis and searching of earthquake traces in the area by the revision of the previously obtained data from different sources. The second part includes direct searching of seismogenic deformations in the rocks and loose sediments of the study area for the confirmation of the hypothesis. Both parts of the study are based on field work.

Authors analysed some tectonic, geologic and stratigraphic data which can be interpreted with point of view of the proposed hypothesis and studied an upper part of the Vuoksi River valley along length about $30 \mathrm{~km}$ from the town of Imatra (the source of the Vuoksi River) to the town of Kamennogorsk looking for seismic deformations in rocks and loose sediments. We discovered and studied previously unknown seismogenic deformations in the Quaternary loose sediments and in the underlying Precambrian crystalline rocks. These deformations were caused by disturbances of different types and ages and indicate differential tectonic movements of late- and post-glacial age. The deformations tend to follow large zone of ancient faults with which the Vuoksi River is closely related. As a result of this study, we provide a new geodynamic approach to the recognition of history and, most importantly, large perturbations of natural environment in the key-area and in the whole region. The formation of the Vuoksi River is associated with seismic processes and the catastrophic water breakthrough of the Saimaa Lake across the boundary ridge Salpausselkä I of about 5700 years ago.

\section{The Vuoksi Fault Zone and some evidence of paleoearthquakes in the area of study}

Valley of the Vuoksi River from the riverhead further south of the Salpausselkä I ridge to $60 \mathrm{~km}$ to the south-east (direction $135^{\circ}$ ) is strictly rectilinear. The valley is characterized by a complete absence of features inherent to normal river development (meanders, stable levels of terraces, etc.). The Vuoksi River valley consists of a significant number of straight channels mainly oriented along the common direction and in less degree at different angles to it (includes the perpendicular directions). The main and secondary directions are strictly structurally determined. The valley is located in the area of large ancient fault, traced by the geological survey. The fault zone, comprising multiple parallel branches with a wide fracture zone separates the two Precambrian granite massifs (Afanosov \& Shuldiner, 1999). The zone is manifested under Quaternary deposits in the form of a narrow trough (Arkhangelsky et al., 1974). Amplitudes of individual vertical displacements can be estimated from drilling data, across one of the eastern branches of VFZ in the area of the Rybnoye Lake to the north of the town Kamennogorsk (Antrea). There is a vertical rock escarp with a height of about $12 \mathrm{~m}$ above the surface of the lake. The flat surface of the crystalline foundation in $10 \mathrm{~m}$ from the escarp to the East, is submerged under glaciofluvial, lacustrine-glacial, and lake sediments at $30 \mathrm{~m}$ (Geissler, 1967). Thus, it is possible to estimate the differential tectonic displacement up to $30-40 \mathrm{~m}$ in the Late Glacial time.

Interpretation of remote sensing data for the region shows a system of linear ruptures in the strip of width of about 5-6 km, expressed in ledges and depressions of topography (Fig. 1). In this area, numerous traces of presumably seismogenic fresh cracks, displacements of rock blocks, landslides, and deformations of unconsolidated sediments have 
previously been documented (Nikonov et al., 2011, 2014). Therefore, there is preliminary evidence of post-glacial tectonic activity of the VFZ and periodical generation of strong earthquakes.

The VFZ crosses the Salpausselkä I ridge and is manifested in the NW from the source of the Vuoksi River (outside study area) in rectilinear shores and scarps on the several islands in the Saimaa Lake (Mietinsaari, Leuduksaari islands etc.). Another complex of linear structures similar to the VFZ and located $9-12 \mathrm{~km}$ to the NE can be traced to SE from the Salpausselkä I ridge along the shores of Immanlahti Lake up to the Novoselovka River valley and further (Fig. 1). Part of this complex is located to the north from Salpausselkä I ridge and can be traced along the scarps bounding the Salosaari Island. It is characteristic that both large fault zones are almost not expressed in accumulative relief of the ridge of Salpausselkä I, but a lot of lineaments of the NE direction can be traced on the ridge system, connecting both fault zones and probably reflecting the post-glacial tensions in the system of these two faults. This part of the Fennoscandian Shield is in the conditions of horizontal compression with a NW orientation of the major axis of the stress field (Ojala et al., 2004). It provides an opportunity to consider the stretching in the sub-latitudinal direction as most likely is the case in a strong earthquake with the opening of the ruptures (possibly shear displacements) at the surface. The channel of the Vuoksi River inherits these presumably echelon faults in the part of the valley that crosses the Salpausselkä I ridge (Fig. 1a). One of these fragments is now the dry rocky gorge in place of the former rapids in the breakthrough valley. The stream of the Vuoksi River is directed into artificial channel at present. It allowed us to detect the structural conditionality of the breakthrough valley by visual examination of the bedrock in the valley.

Secondly, we can state that the structural position of the Vuoksi River source on the intersection of VFZ and the Salpausselkä I water barrier enables us to study the influence of the VFZ seismic activity to the destruction of the
Salpausselkä I ridge and the formation of a gap to outpouring Saimaa Lake waters.

Before the consideration of our own direct observations showing the past seismic activity of VFZ, we can discuss some previously obtained geological data in the study area or close to it. One of such sources is drilling data from the bottom of the Lake Saimaa (Pajunen, 2004). Standard cross-section of bottom sediments is composed of horizons (from bottom to top): a) varved clays, b) silt or clay, and c) gyttja (with variations and transitional horizons) (Pajunen, 2004). Respective paleogeographical interpretation is quite specific: a) Baltic Ice Lake (BIL), b) a deep lake with minimal flow of organic matter, and c) a lake basin with the deposition of large amounts of organic material. The boundaries between the horizons are sharp, sometimes with a thin transition layer. The first sharp transition coincides with the well-known information about BIL breakthrough in Sweden at Mt. Billingen (Björck, 1995) and the subsequent rapid fall in the water level $(28-25 \mathrm{~m})$ at $11.5 \mathrm{cal}$. kyr BP. An equally dramatic decline of the Saimaa waters in all columns of bottom sediments of the area is marked by a sharp contact between the silt, less often clay, and gyttja. This boundary is fixed everywhere, and its age is estimated from 10.7 to 10.8-11 cal. kyr BP (Pajunen, 2004). Several anomalies were detected in the drilling columns, however. Abnormal structure of layers has been detected in the column \#6 (Pajunen, 2004) of bottom deposits near the southern shore of the Lake Saimaa (near town of Imatra). In the borehole at a depth of 2.94-2.83 m below the bottom of the lake, a layer of silt was found, which is overlain by peat with a thickness of $0.83 \mathrm{~m}$. The peat layer, in turn, is covered by gyttja "mixed with peat" of $0.4 \mathrm{~m}$ thickness, and above, up to the bottom of the lake, lies monotonous gyttja. Peat layer thickness of $0.8 \mathrm{~m}$ at the site near Imatra clearly indicates the existence of long subaerial conditions. The time of peat accumulation, i.e., the existence of subaerial conditions in this place, fits exactly to the interval of $10260-9550$ cal. yr BP given by the ${ }^{14} \mathrm{C}$-data 
from the lower and upper layers (Pajunen, 2004). The reason of land drainage can be attributed to differential tectonic uplift of the local block about $10.3 \mathrm{cal}$. kyr BP. It is also unusual that overlying peat layer (with a thickness of $0.4 \mathrm{~m}$ ) was mixed with gyttja. It is obvious that it represents a mixture of continental and lake sediments and was removed from its primary, in situ position. These features reflect the strong water disturbance immediately after the completion of the peat formation. After this event, lacustrine regime begun and persevered without interruption to the present. We can suggest a tsunami in the basin of the Saimaa Lake, connected to strong earthquake about $9.5 \mathrm{cal}$. kyr BP, as one of probable explanations for this abnormal structure of sediments.

Another atypical section (\#16) was found in the southern part of Lake Saimaa at a distance of $10-16 \mathrm{~km}$ from the coast (Pajunen, 2004). The section of bottom sediments was obtained in the narrow strait between islands with NW orientation. The layer of gyttja lies on the silt and clay with an abrupt boundary. The thickness of gyttja $(2 \mathrm{~m})$ is significantly reduced in comparison with the standard data $(3.5-5 \mathrm{~m})$ and, consequently, records a shortened accumulation period. The age of the lower part here is 5.7 cal. kyr BP, against 11.0 cal. kyr BP in the standard sections (Pajunen, 2004). Intense erosion of the lower part of gyttja, as well as in the first case, can be explained by a powerful flow, probably tsunami, associated with an earthquake. An exact coincidence of the age of beginning of gyttja accumulation after catastrophic erosion (Pajunen, 2004) and the accurate time of origination of the Vuoksi River (Saarnisto, 1970; Remes et al., 2013) allows us to put these events in connection.

Other type of data which can be interpreted as the evidence of earthquakes were obtained earlier in quarries located in the area of the study (Donner et al., 1968; Aartolahti, 1970; Gibbard \& Saarnisto, 1977; Donner \& Delusin, 1995). A considerable number of wedge-shaped structures and some other types of deformations in late- and post-glacial unconsolidated sediments were found here. These forms are represented by vertical ruptures in the horizontal delta sediments with weakly eroded ground surface. Most of the wedges have a depth of $1.5-2.5 \mathrm{~m}$. All the dislocations were interpreted as signs of permafrost and related to the phase of Younger Dryas. However, a detailed classification of these phenomena for this area has not been done (Donner \& Delusin, 1995). Some signs indicating alternative genesis can be observed, among which are: a) epigenetic (single event) formation of the majority of cracks, b) formation of some of the cracks without filling, and c) the presence of such traces as stretching and compression in the structure of wedges. Similar deformations are reasonably interpreted as seismogenic (Nikonov et al., 2005; Nikonov \& Rusakov, 2010; Shvarev et al., 2018). The most complete cross-section is located in Joutsenokangas quarry $25 \mathrm{~km} \mathrm{SW}$ from the Vuoksi River headwater (Saarnisto, 1977). A two-stage structure, in which two horizons of deformations are divided by a layer of parallellaminated sands, can be found there. The difference of the deformations is that the top tier reflects only the single event stretching in the NW-direction, whereas the lower tier reflects two stages: first is stretching and formation of the wedges due to extension, and second one reflects compression. This situation cannot be explained by uneven load of $3 \mathrm{~m}$ of homogeneous strata of sandy pebble material as it was assumed earlier (Saarnisto, 1977). Both groups of deformations indicate their occurrence as a result of instantaneous lateral dynamic effects. The impulses that gave rise to these deformations can be related to abnormalities in the bottom sediments in the Saimaa Lake approximately $9.5 \mathrm{cal}$. kyr BP, or to the event that resulted in the breakthrough of the Vuoksi River 5.7 cal. kyr BP.

Separate interpretations of these phenomena can lead to different conclusions about their genesis including permafrost (Saarnisto, 1977) or numerous lake transgressions (Pajunen, 2005). However, this data can be interpreted from another point of view: strong seismic events and 
differential tectonic displacements of different ages. Complex analysis of specific characteristics of the Vuoksi River valley and the adjacent area suggest the possibility of the Saimaa Lake breakthrough through the marginal Salpausselkä I ridge due to a large earthquake and possibly following a strong tsunami. Such a situation is not a single phenomenon within the SE flank of the Fennoscandian Shield - traces of similar cataclysm have been discovered there previously (Nikonov $\&$ Subetto, 2007; Nikonov, 2008, 2009, 2017).

Thirdly, we can state that the disturbances in the loose deposits in the basin of the Saimaa Lake and in the Salpausselkä I ridge in the area under study exhibit signs of strong seismic events. And fourth, the ages of these deformations closely relate to the birth of the Vuoksi River and allow us to connect the river breakthrough with a strong earthquake.

Based on this hypothesis, we focused our searches on the direct traces of seismic effects: a) detection of the deformations directly on the site of the breakthrough (spatial localization) and b) detection of deformations of the corresponding age (temporal determination). We argue to have managed to find some traces of seismogenic impact in the rocks near the headwater of the Vuoksi River and in the deposits of the low terraces downstream (Fig. 1).

\section{Seismogenic deformations in the rock substrate: the headwaters area of the Vuoksi River}

Seismogenic deformations were found in the rocks on the site of the former thresholds on the Vuoksi River, where the gorge of breakthrough is located (Fig. 1a). This place was first described as the place of catastrophic water stream by Sederholm (1897).

The morphology of the breakthrough valley has several specific features (Fig. 2a, b): 1) straightness of over $700 \mathrm{~m}, 2) \mathrm{NE}$ orientation $\left(45^{\circ}\right)$, and
3) asymmetry of perpendicular cross-section profile with gentle western and steep eastern slopes. According to modern concept, initial formation of the gorge occurred due to the random denudation (local erosion) of relatively unstable strata of crystalline shale, which lies between the granites, when the waters of the Saimaa Lake crossed marginal Salpausselkä I ridge. Asymmetric form of the gorge is connected to an inclination of the rock layers to the east. Western side of the gorge is a consequent slope corresponding to the geologic structure. Eastern scarp is an inconsequent slope, characterized by abrupt scarp and processes of weathering and gravitational demolition which is still taking place today (Fig. 2b, inset) (Remes et al., 2013).

We discovered that there are clear traces of postglacial seismic effects, located on both sides of the valley and not related to processes of weathering and gravitational destruction. The seismogenic deformations present several typical features: vertical longitudinal tear with displacement of the lateral wings to several tens of $\mathrm{cm}$ and transverse cracks with the offset of adjacent blocks and the fragmentation of bedrock. This set of deformations determines the shear ensemble caused by the postglacial seismic impulse of ancient fault zone.

The right (western) riverside slope of about $25^{\circ}$ has a straight transverse profile and a smooth surface, indicating prolonged exposure to erosion. Upper granite layer was partially removed by the gravitational demolition initiated by river erosion. In some places, the slope exhibits steps caused by the orthogonal system of longitudinal and transverse cracks. Most of the cracks are closed and the sutures between the blocks are smooth. However, one of slope cracks longitudinal to the valley and perpendicular to the surface is open, dipping to the NW $\left(70-75^{\circ}\right)$, and forms several local cavities generated by lateral displacement of the blocks relative to each other (western wing moved to the south, eastern wing to the north) up to 20-40 $\mathrm{cm}$ (Fig. 2c). We can explain the displacement of rock massif parts along vertical cracks only 


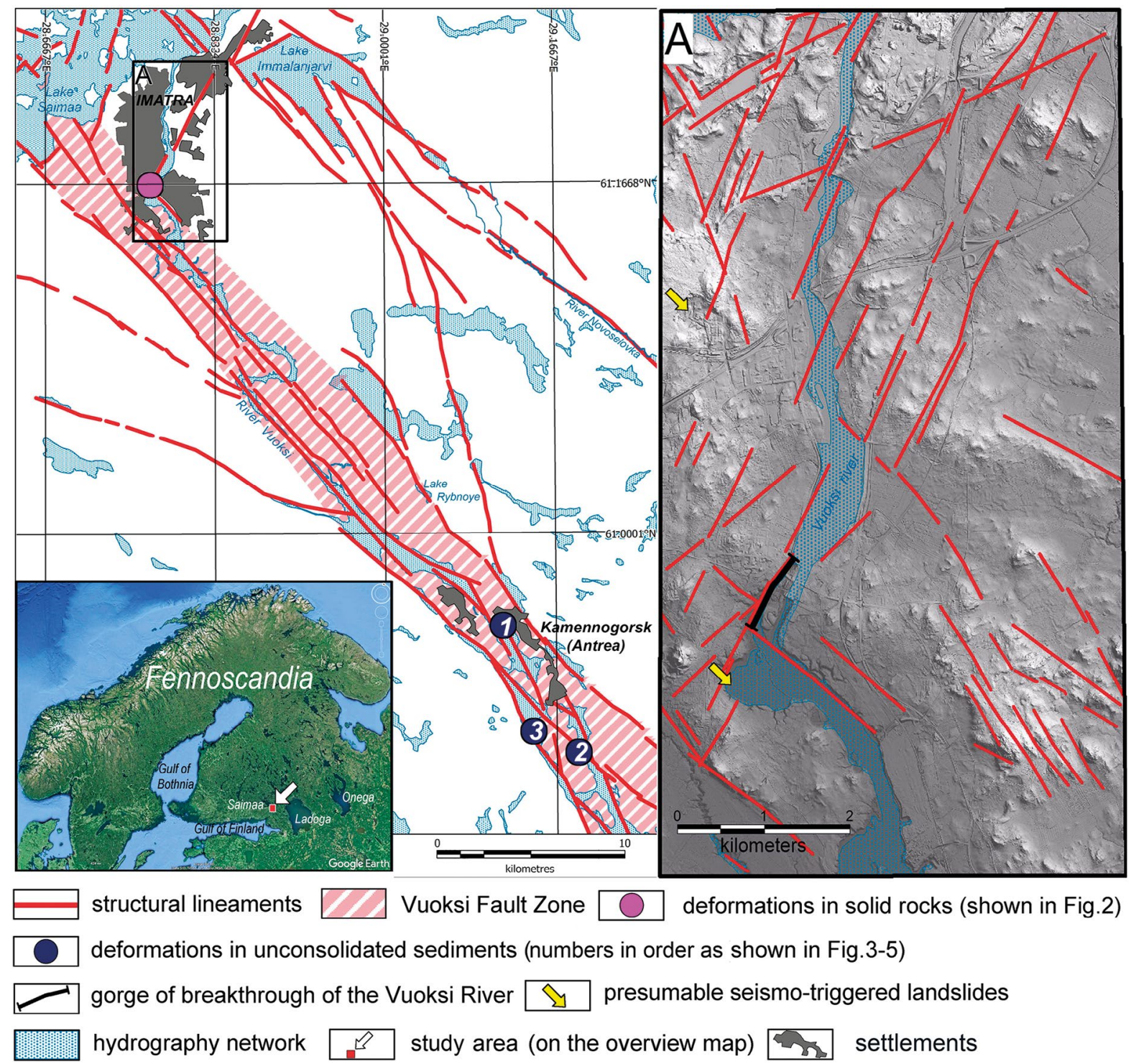

Figure 1. Scheme of the Vuoksi Fault Zone and the areas of deformations. Inset a) Detailed scheme of present situation at the area of the Vuoksi River headwaters.

by endogenous (seismogenic) factors and shear kinematics. The intensity of the seismic impulse can reach VIII-IX points at the point of observation according to ESI 2007 (Michetti et al., 2007), estimated mainly by the surface faults with offsets from first $\mathrm{cm}$ to first tens of $\mathrm{cm}$. Several open cracks were discovered on the eastern bank with steepness up to $70-75^{\circ}$ transverse to the direction of the gorge (Fig. 2d). The displacement of the blocks is noticeable along the river to the north to a distance of about $10-20 \mathrm{~cm}$. The signs of tectonic origin of the cracks are both horizontal displacement of blocks against the river's current, and the occurrence of the cracks at the depth of about $2 \mathrm{~m}$ and below without reaching the surface. Opposite horizontal offset on different sides of the gorge indicates 

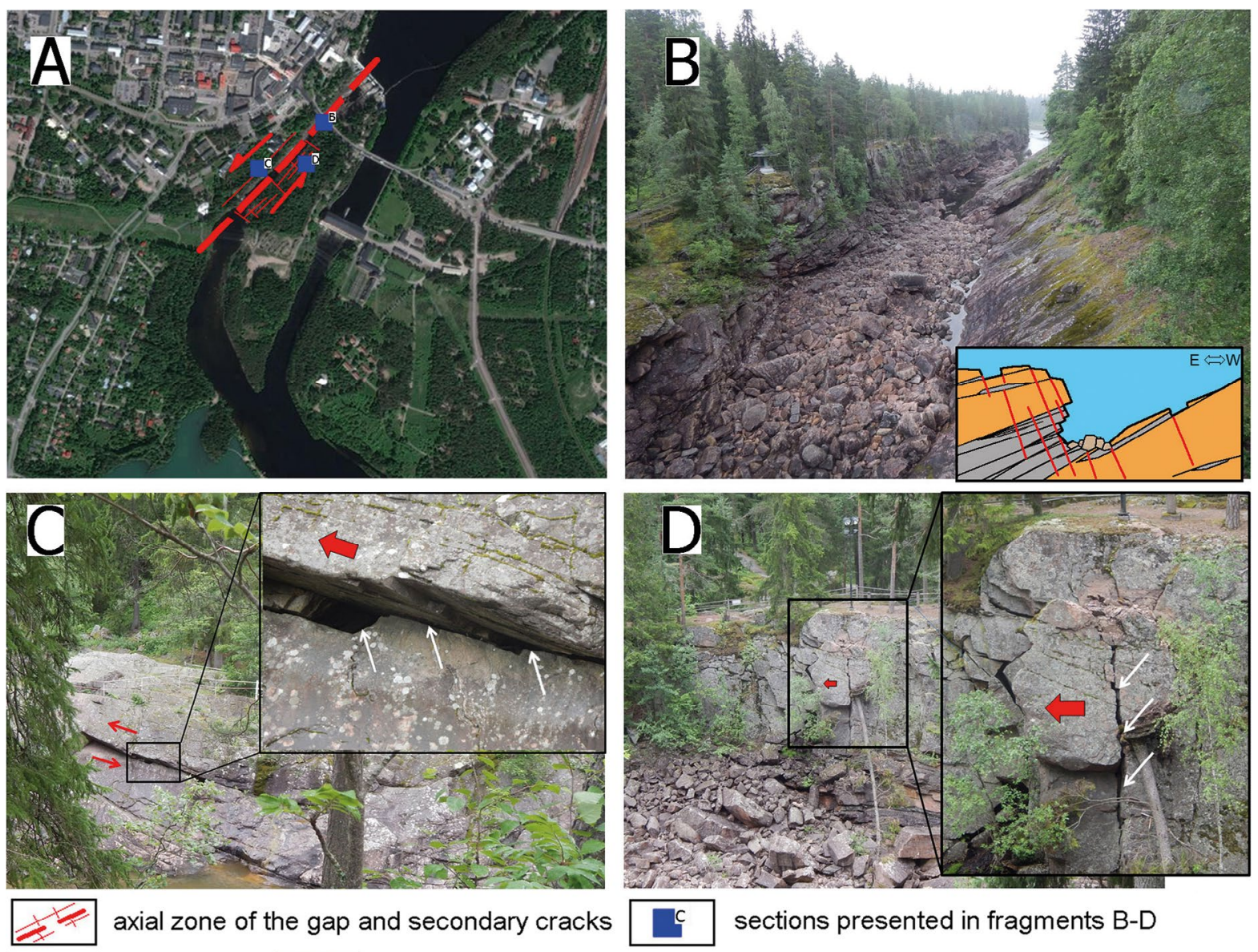

axial zone of the gap and secondary cracks
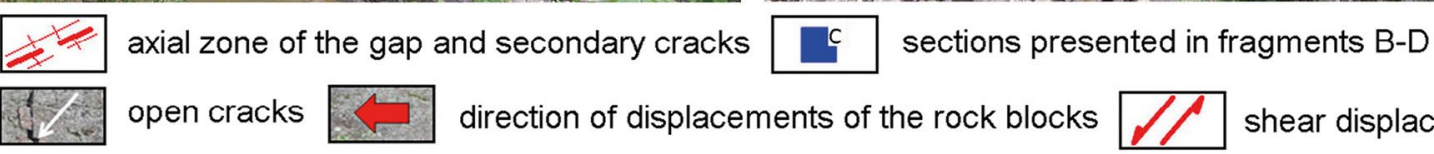

open cracks

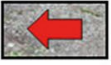
direction of displacements of the rock blocks

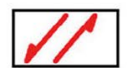
shear displacements

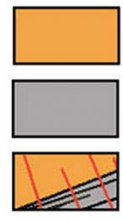

granites

cristalline schists

to the cross-section (inset B) cracks in the rocks

Figure 2. Seismogenic deformations in the rock bed of the breakthrough valley of the Vuoksi River. a) Satellite image. b) General view of the breakthrough valley and a schematic cross-section (in the inset) (Remes et al., 2013). c) Lateral displacement of blocks of the right bank of the valley to the south. d) Lateral displacement of blocks of the left bank of the valley to the north.

a sinistral shift with an axial zone in the valley of a breakthrough.

It should be noted, that complex primary and secondary earthquake effects in the gorge can be supplemented by presumably earthquake-triggered large landslides in the Vuoksi River headwaters area.
Places with some signs of such forms can be detected with the help of the LIDAR data, provided by the Geological Survey of Finland (GTK) (Fig. 1a). However, a more detailed study for evaluating this assumption and the age of these formations is necessary. 
Another view is related to a possible effect of large water reservoir as a trigger to earthquake. Such cases of induced earthquakes are very widespread (Nikonov, 1977; Gupta, 2002), but in cases of significant earthquakes of $M>5$ to be triggered, pre-existing faults to generate such earthquakes must exist in the vicinity of the reservoir (McGarr \& Simpson, 1997). In any case, the earthquake of such intensity as was estimate in Saimaa case (VIII-IX points) could not be generated without influence of permanent seismically active fault. The VFZ with the signs of some earthquakes of different ages (Nikonov et al., 2014) has all optimal parameters for such structure to be taken into account.

\section{Seismogenic deformations in loose deposits: the middle reaches of the Vuoksi River}

Downstream, near the town Kamennogorsk (Antrea) we studied the complex of terraces, including levels with relative height above river level of 14-15 m, 6-7 m, and 3-4 m. We have detected deformations with obvious signs of seismic effects of different ages or related catastrophic processes in loose deposits at all levels. The youngest deformations are confined to the sediments of the terrace with relative height of 3-4 meters, as shown in Figs. 3-5. We have discovered that the structural patterns of sediments are completely different, although the cross-sections are only few $\mathrm{km}$ apart. The sediment sequence of the area studied first consists of parallel stratified sandy layers with interbeds of gravel and silt inclined to the north. The sub-latitudinal fault dissects the stratum with amplitude of displacement of $0.3 \mathrm{~m}$ (Fig. 3). In the second area, north-dipping sandy layers are characterized by a change in the inclination angle, from $30^{\circ}$ to $10^{\circ}$ at the top. We presume that the inclination of layers is secondary. Firstly, so fine material with parallel layers could be deposited in stagnant or slow stream conditions. This also means that the structure was initially horizontal. Secondly, there are signs of inner microfolding inside some layers of sand and silt. These microfolds could have formed due to the sudden inclination of initially horizontal layers (Fig. 4). In the third area, the terrace is composed of unsorted boulder and gravel-pebble sediments with sandy-silt matrix and fragments of varved clays, covered with several subhorizontal layers of sand and silt (Fig. 5).

The common feature of all three studied sections is two-tiered stratigraphy of the terrace bodies with the deformed lower part (complexes II-III in Figs. 3, $4,5)$ and the undisturbed upper part consisting of sub-horizontal, weakly stratified layers (complex I).

It can reasonably be assumed that the ruptures and inclination of layers in a body of 3-4 m high terrace are connected with cracks of the rocks under loose deposits and different displacements of tectonic blocks, in turn caused by strong seismic motions, whereas chaotic mixture of blocks, boulders and varved clay fragments is the result of the debris flow simultaneous to the earthquake.

Absolute age determinations of the terraces in all three locations is not yet available due to the lack of organic residues. However, we can estimate it based on the age of the adjacent levels. Age of plant detritus in the upper part of terrace at a relative height of $0.5 \mathrm{~m}$ above the level of the Vuoksi River ( $\mathrm{h}=9 \mathrm{~m}$ a.s.l.) is $1930 \pm 40{ }^{14} \mathrm{C} \mathrm{yr}$ BP (1.8 cal. kyr BP) (GIN-15442). Higher level of 6-7 $\mathrm{m}$ terrace $(\mathrm{h}=14-15 \mathrm{~m}$ a.s.l.) has an age of $7410 \pm 110{ }^{14} \mathrm{C}$ yr BP (8.3 cal. kyr BP) (GIN-15444) (fig. 6, fragment B). Thus, we can calculate the lower and upper limit of the age for the terrace of 3-4 m ( $h=12 \mathrm{~m}$ a.s.l.), which was formed in the valley of the Vuoksi River after a catastrophic event, with vertical displacement along faults, steepening of loose deposits, intensive erosion and extraction of varved clays fragments from the bed, and the formation of coarse (seismo)-proluvial strata. 


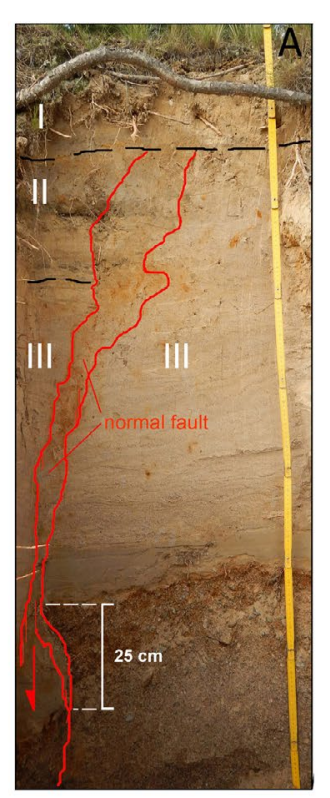

Complexes of sediments

undeformed part

I - overlapping complex of quasi horizontal sands:

deformed part

II - weakly sloped sandy loam and sands

(only in the lowered wing - on the left of the cross-section,

eroded in the raised wing - on the right of the cross-section)

III - weakly sloped loams, sandy loams, sands, gravel and pebbles (more coarse material on the bottom)
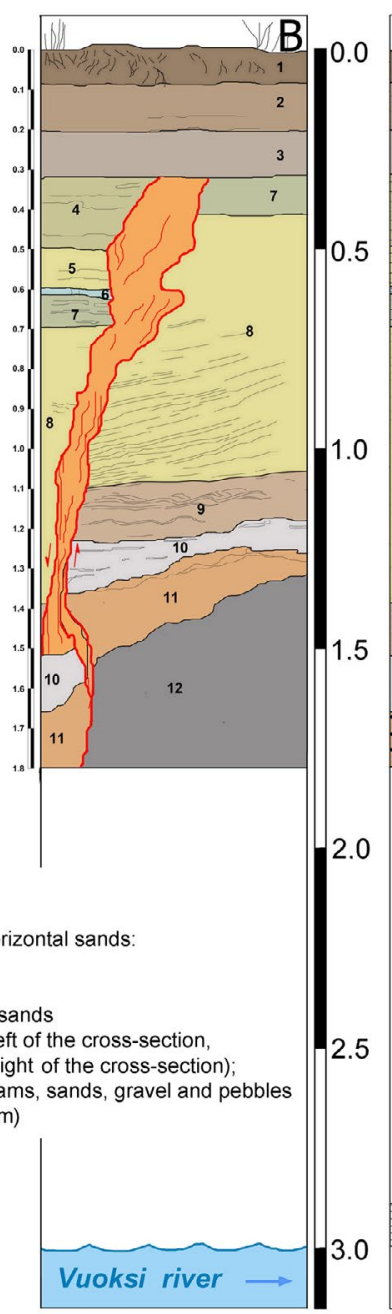

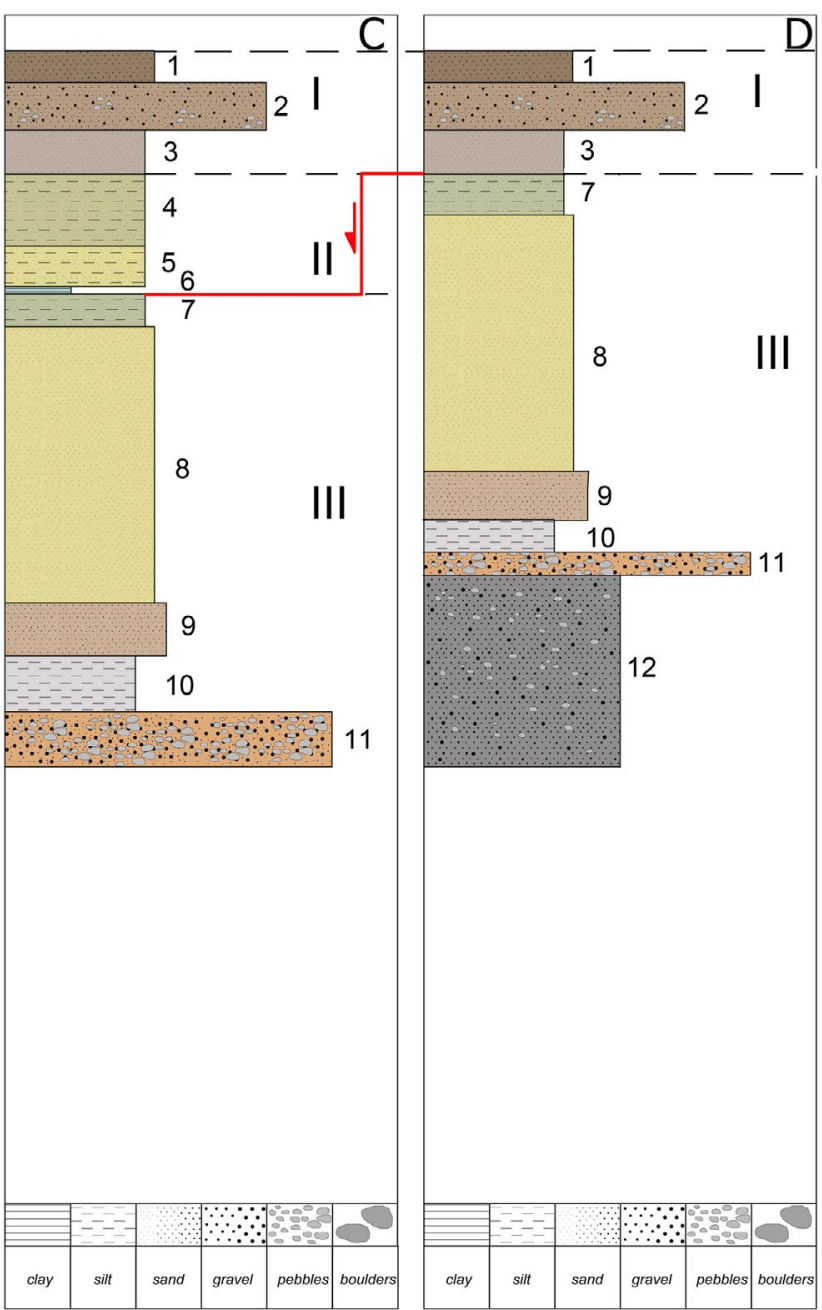

Figure 3. Cross-section 1. Vertical displacement of the sand and gravel strata by the normal fault in the terrace with relative height of $3.0 \mathrm{~m}$ above the level of the Vuoksi River (see Fig. 1 for location of the cross section). a) Photo. b) Drawing from photographs. c,d) Western (left) and eastern (right) edges of the cross-section, respectively.

\section{Discussion}

Our research proposes an alternative for hydrography network development in comparison with the traditional point of view based on stepby-step increasing of the basin level as a result of post-glacial rebound, accumulation of water in front of ridge Salpausselkä I and final overflow. Our considerations for the revision of tectonic, geologic and stratigraphic data have been described in relevant sections. Here we cover some important questions regarding our data and its interpretation.

Firstly, there is a question about genesis of open cracks and gaps discovered in the breakthrough valley: can they be of gravitational or weathering or glacial origin? The cracks have sharp edges and breaks on the smoothened surfaces which were formed by the glaciofluvial streams. Therefore, the 

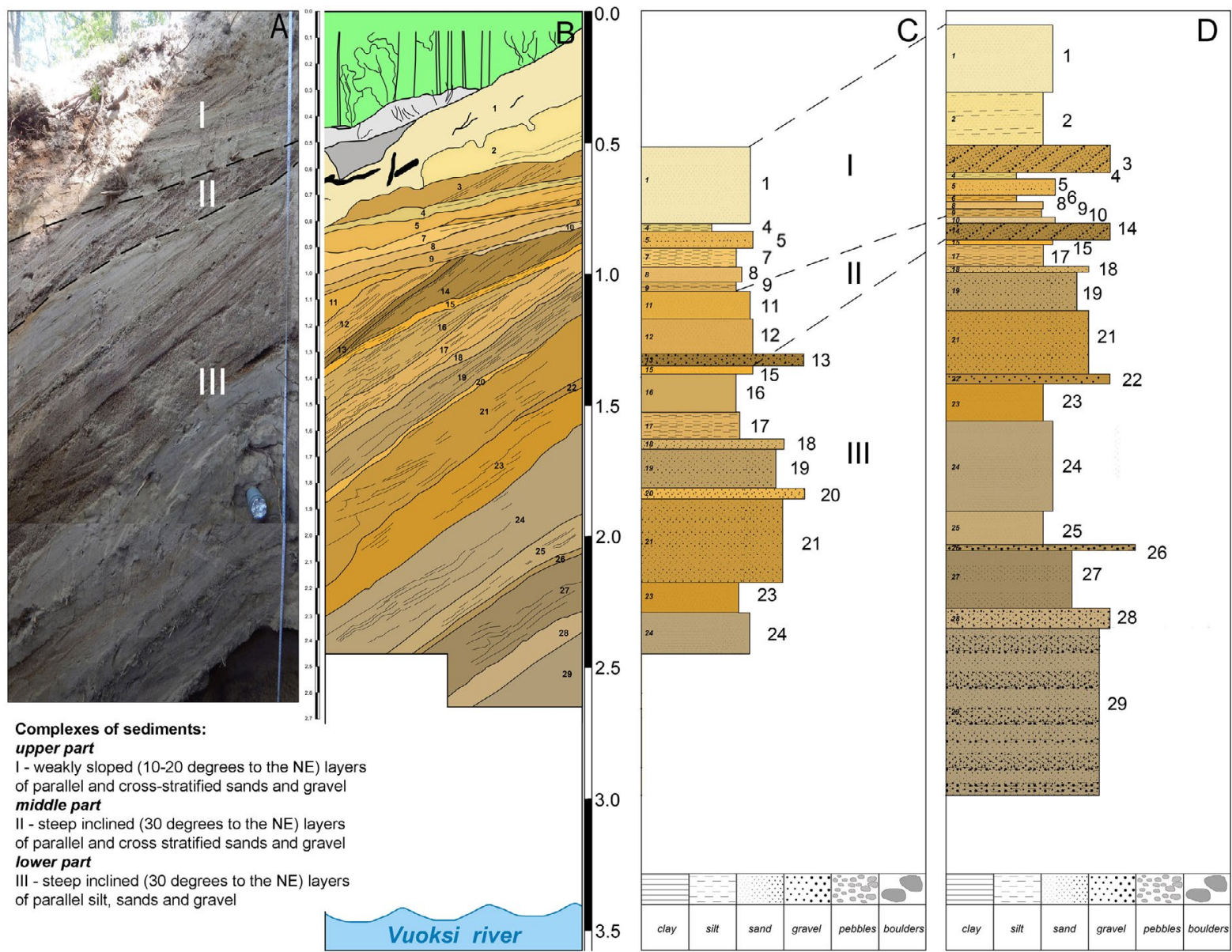

Figure 4. Cross-section 2 (3-4 m terrace level) with steeply sloped sand layers (see Fig. 1 for location of the cross section). a) Photo. b) Drawing from photographs. c,d) Western (left) and eastern (right) edges of the cross-section, respectively.

timing of formation of the cracks can be related to the period after retreat of the last glacier. The quasivertical character of the cracks and displacements of large parts of massif along the gorge and alongside the dissected slope cannot be interpreted as traces of weathering or gravitational processes.

Secondly, there is a question about the genesis of deformations in loose sediments, discovered in the low terraces: can they also be of gravitational or cryogenic origin? We cannot find any signs of gravitational forms in the topography that could be connected with the revealed deformations. The timing of formation of the terrace relates to interval from Boreal to Sub-Atlantic climatic periods and cannot be connected with the presence of cryogenic conditions in the area.

The newly obtained and previously released data give a reasonable, but schematic picture, which needs to be supplemented. However, it currently provides a foundation for a more detailed spatiotemporal analysis of the data. 


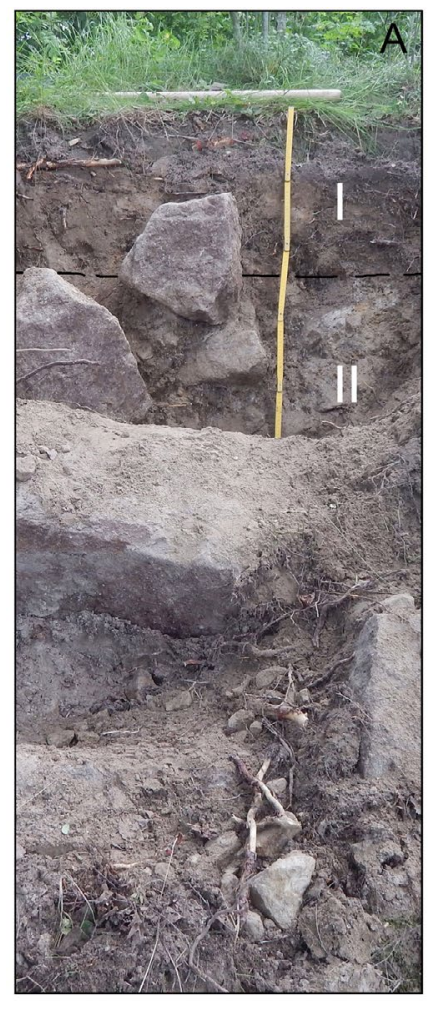

Complexes of sediments: upper complex (overlapping) I - quasi horizontal layers of silt and sands lower compex II - unsorted boulders and blocks in sandy-silt matrix with fragments of varved clays
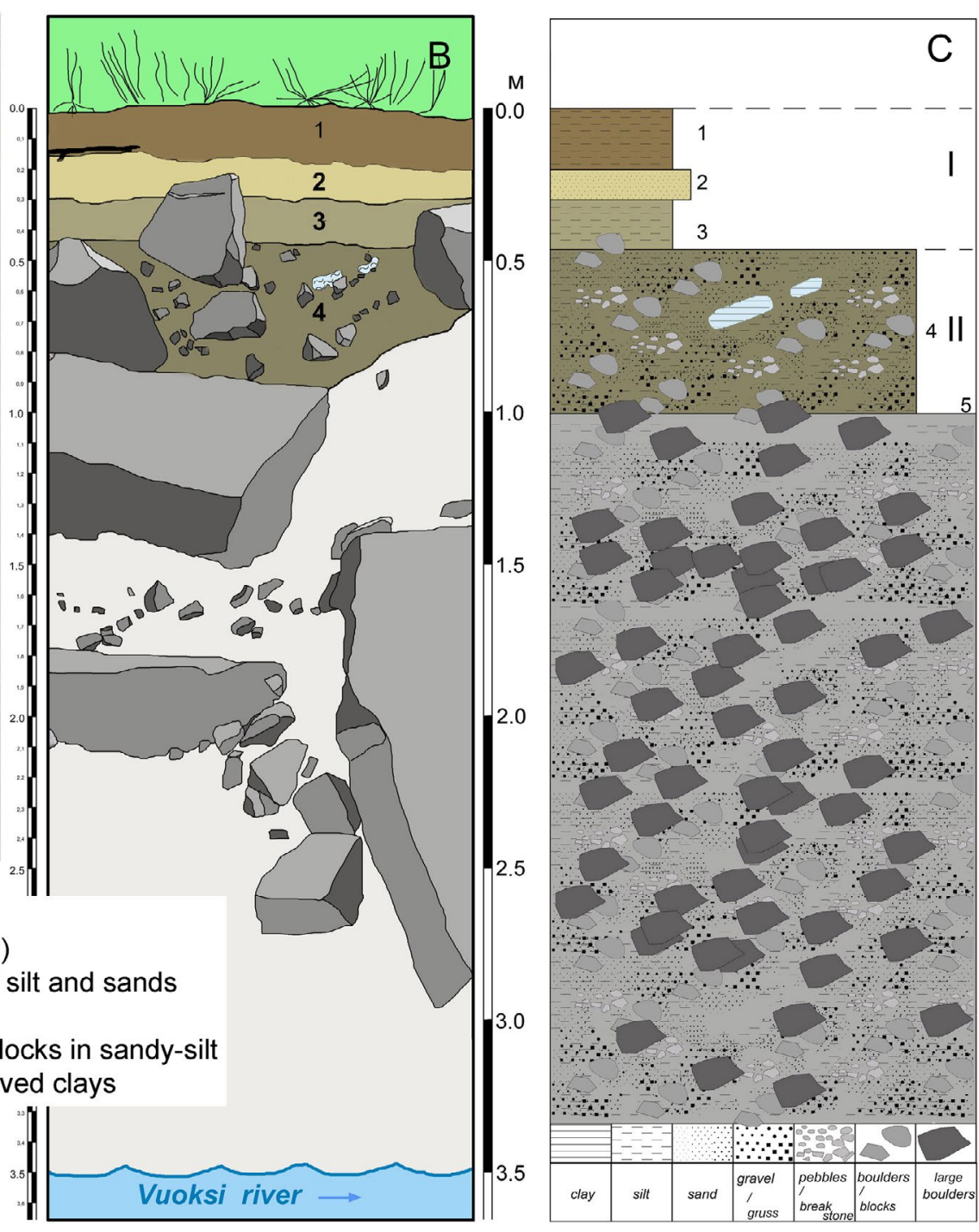

Figure 5. Cross-section 3 with mudflows on (proluvial) unsorted deposits. a) Photo. b) Drawing from the photo. c) Crosssection.

\section{Conclusion}

Research was initiated to test a hypothesis about the influence of strong earthquakes on the formation of the Vuoksi River and the relationship of this event with the post-glacial activation of the VFZ. A survey of the upper reaches of the river helped to identify certain characteristics of seismic origin for the deformations in the rocky substrate of the river bed. These deformations are a combination of signs indicating the shear kinematics of the fault. The intensity of the seismic event corresponds to VIII-IX points of the Intensity Scale ESI 2007 estimated mainly by the surface faults with detected offsets from first $\mathrm{cm}$ to first tens of $\mathrm{cm}$ near the Imatra town. Seismogenic deformations in unconsolidated sediments were discovered, including the terrace of $3-4 \mathrm{~m}$ relative height for several tens of kilometres downstream. The structure of sediments of this terrace is completely 


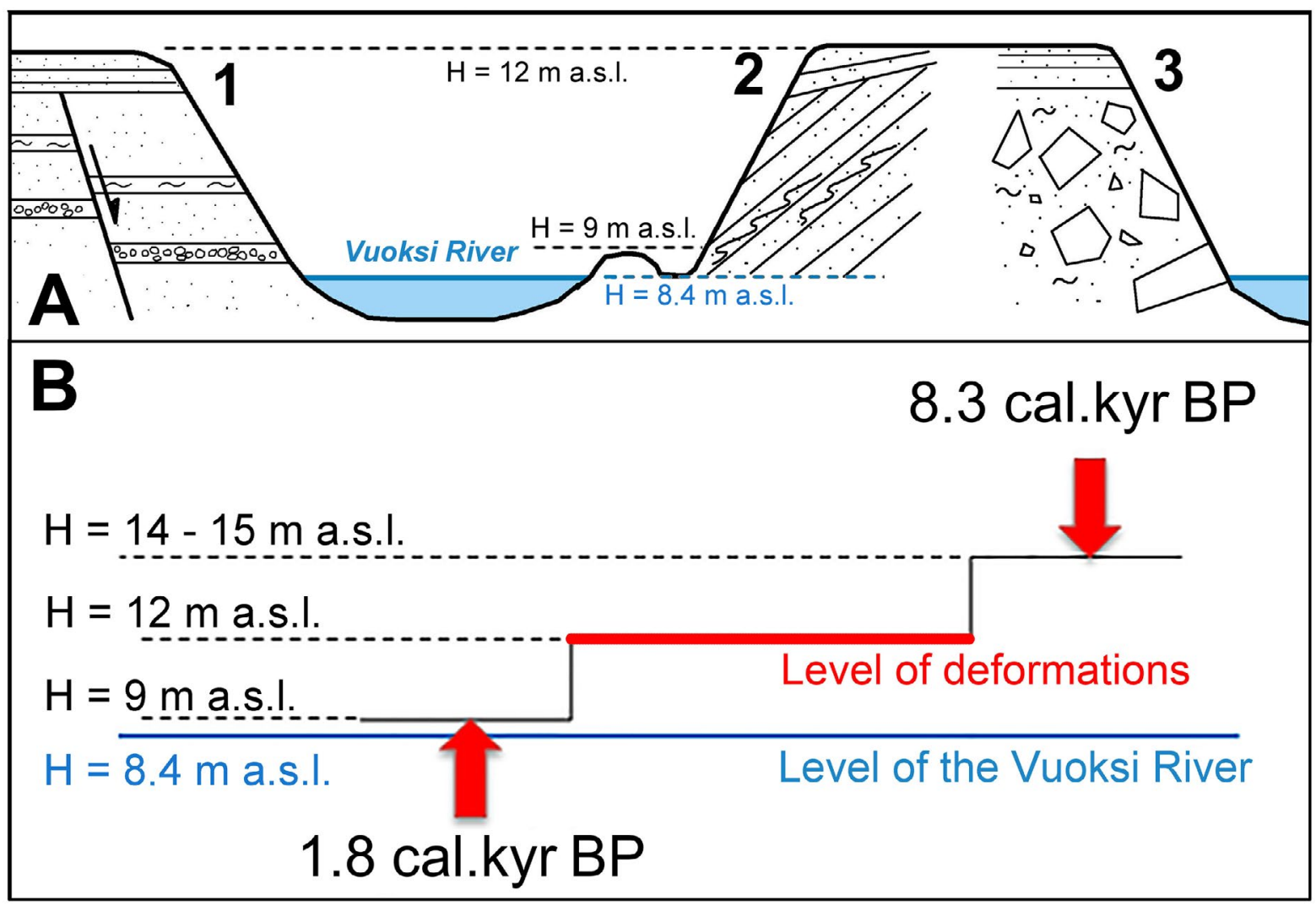

Figure 6. Correlation of the cross-sections. a) Principal diagram of the cross-sections. b) Scheme of age-related correlation of the terraced levels.

different, although the cross-sections are only few $\mathrm{km}$ apart. We have found faults with offsets, tectonic tilting of initially horizontal sediments, and proluvial and mudflow deposits at several outcrops. An estimated age of tectonic deformation between 2-8 kyr BP was calculated using the youngest deformed sediments (3-4 m terrace level) and absolute ages at adjacent stratigraphic levels. This is consistent with the age of formation of the Vuoksi River (5.7 cal. kyr BP). We have identified deformed layers at other terrace levels of the Vuoksi River, probably older in age. This suggests the occurrence of repeated late-glacial and Holocene strong seismic events in the VFZ and their impacts in changes of hydrographic conditions of the Karelian Isthmus. Immediate tasks for future research are determining the exact age of deformation at all levels and reconstructing the hydrography, topography, and landscapes which changed because of the influence of differential tectonic displacements.

\section{Acknowledgments}

The study is supported by the Russian Fund for Basic Research (project 16-05-00727), and under the NWPI research topic 0223-2014-0012, the IG RAS research topic 0148-2014-00016, the IPE RAS research topic 0144-2014-0097 and the GIN RAS research topic 0135-2014-0068. We thank all reviewers for valuable comments, especially Dr. Rosa Ayola and Dr. Keijo Nenonen for the concrete recommendations and suggestions. 


\section{References}

Aartolahti, T., 1970. Fossil ice-wedge, tundra polygons and recent frost cracks in southern Finland. Annales Academiae Scientiarum Fennicae. Ser. A III GeologicaGeographica 107, 1-26.

Afanasov M.N. \& Shuldiner V.I. (eds.), 1999. State geological map of Russian Federation. The Karelian Series. Scale 1: 200 000. P-35-XXIX, XXX. St.-Petersburg. (in Russian).

Arkhangelsky G., Gostintsev V. B., \& Alexandrova T. V. (eds.), 1974. Hypsometric map of the pre-Quaternary surface deposits. Scale 1: 500 000. Comp. Report on the topic: geological mapping of scale 1:500000, Leningrad. (in Russian)

Björck S., 1995. A review of the history of the Baltic Sea, 13.0-8.0 ka BP. Quaternary International 27, 19-40. https://doi.org/10.1016/1040-6182(94)00057-c

Bungum, H. \& Lindholm, C., 1997. Seismo- and neotectonics in Finnmark, Kola Peninsula and the Southern Barents Sea. Pt. 2. Seismological analysis and seismotectonics. Tectonophysics 270, 15-28. https://doi.org/10.1016/s0040-1951(96)00139-4

Dehls, J.F., Olesen, O., Olsen, L. \& Blikra, L.H., 2000. Neotectonic faulting in Northern Norway: The Stuoragurra and Nordmannvikdalen postglacial faults. Quaternary Science Reviews 19, 1447-1460. https://doi.org/10.1016/s0277-3791(00)00073-1

Donner J. \& Delusin I., 1995. Late Weichselian periglacial features in south-eastern Finland and the surroundings of Lake Ladoga in Russia. Bulletin of the Geological Society of Finland 67:11, 65-72. https://doi.org/10.17741/bgsf/67.2.005

Donner J., Lappalainen V. \& West R.G., 1968. Ice wedges in south-eastern Finland. Geologiska Föreningen i Stockholm Förhandlingar 90, 112-116. https://doi.org/10.1080/11035896809448395

Geissler, E.L., 1967. Lake basins of the Karelian Isthmus. History of lakes of the North-West. L. 323-368. (in Russian).

Gibbard, P. \& Saarnisto M., 1977. Periglacial phenomena at Tohmajärvi, eastern Finland. Geologiska Föreningen i Stockholm Förhandlingar 99, 295-298.

https://doi.org/10.1080/11035897709455027

Gupta, H.K., 2002. A review of recent studies of triggered earthquakes by artificial water reservoirs with special emphasis on earthquakes in Koyna, India. Earth-Science Reviews 58, 279-310. https://doi.org/10.1016/s0012-8252(02)00063-6

Kuivamäki, A., Vuorela, P. \& Paananen, M., 1998. Indications of postglacial and recent bedrock movements in Finland and Russian Karelia. Geological Survey of Finland, Nuclear Waste Disposal Research, Report YST-99, 92 p.

Kujansuu, R., 1964. Nuorista siirroksista Lapissa. Summary: Recent faults in Lapland, Geologi 16, 30-36.
Kukkonen, I.T., Ask, M.V.S. \& Olesen, O., 2011. Postglacial fault drilling in Northern Europe: Workshop in Skokloster, Sweden. Scientific Drilling 11, 56-59. https://doi.org/10.5194/sd-11-56-2011

Lagerbäck, R. \& Sundh, M., 2008. Early Holocene faulting and paleoseismicity in northern Sweden. Geological Survey of Sweden, Research Paper C836, 84 p.

Lukashov, A.D., 1995. Paleoseismotectonics in the Northern Part of Lake Onega (Zaonezhsky Peninsula, Russian Karelia). Geological Survey of Finland, Nuclear Waste Disposal Research Report YST-90.

Lukashov, A.D., 2004. Recent geodynamics. In: Sharov N.V. (ed.), Deep Structure and Seismicity of Karelian Region and Its Framing. Petrozavodsk, pp. 150.

Lundqvist, J. \& Lagerbäck, R., 1976. The Parvie fault: A lateglacial fault in the Precambrian of Swedish Lapland. Geologiska Föreningen i Stockholm Förhandlingar 98, 45-51. https://doi.org/10.1080/11035897609454337

McGarr, A. \& Simpson, D., 1997. Keynote lecture: A broad look at induced and triggered seismicity, "Rockbursts and seismicity in mines". In: Gibowicz, S.J., Lasocki, S. (Eds.), Proceedings of 4th International Symposium on Rockbursts and Seismicity in Mines, Poland, 11- 14 Aug, 1997. A.A. Balkema, Rotterdam, pp. 385-396.

Michetti, A.M., Esposito E., Guerrieri, L., Porfido, S., Serva, L., Tatevossian, R., Vittori, E., Audemard, F., Azuma, T., Clague, J., Comerci, V., Gürpinar, A., Mc Calpin, J., Mohammadioun, B., Mörner, N.A., Ota, Y. \& Roghozin, E., 2007. Intensity Scale ESI 2007. In: L. Guerrieri \& E. Vittori (eds.), Mem. Descr. Carta Geologica d'Italia Servizio Geologico d'Italia, Dipartimento Difesa del Suolo, APAT, Rome, Italy, 74.

Mörner, N.-A., 2003. Paleoseismicity of Sweden - a novel paradigm. P\&G unit, Stockholm University. 320 p.

Nikolaeva, S.B., 2008. Disastrous earthquakes in the vicinities of the town of Murmansk: Paleoseismological and geological evidence. Journal of Volcanology and Seismology 2, 189-198. https://doi.org/10.1134/s0742046308030068

Nikolaeva, S.B., Nikonov, A.A., Shvarev, S.V. \& Rodkin, M.V., 2016. Comprehensive paleoseismic geological studies in a key site in southwestern Kola Peninsula (Northeast of the Fennoscandian Shield). Doklady Earth Sciences 469, 656-660. https://doi.org/10.1134/s1028334x16070138

Nikonov, A.A., 1977. Recent crustal movements. Moscow: "Nauka", 240 p. (in Russian).

Nikonov, A.A., 2002. Earthquakes and paleoearthquakes in South-East border of the Baltic shield. European Seismological Commission (ESC) XXVIII General Assembly. Genoa, Palazzo Ducale, 1-6 Sept., 207-210. 
Nikonov, A.A., 2003. Fennoscandia - an underestimated seismogenic province. In: Geophysics of XXI century, Year 2002. Collection of papers of IV geophysical readings in V.V. Fedynsky memory. Moscow: "Nauchnyi mir”, pp. 207-214. (in Russian)

Nikonov, A.A., 2007. Extreme natural phenomena in the Northern Ladoga region from the geological, landscape, and historical points of view, History and Cultural Heritage of the Northern Ladoga Region Viewed from Two Sides: Proceedings of the II International Conference, Sortavala, Russia, pp. 16. (in Russian).

Nikonov, A.A., 2008. Man of Stone Age at the Ladoga Lake (to the 125 th anniversary of the paper by A.A. Inostrantsev). Priroda 7, 26-34. (in Russian).

Nikonov, A.A., 2009. Rising of the Newa river - stormy and secret. Society, environment, development 1, 212-229. (in Russian).

Nikonov, A.A., 2017. Impacts of Holocene perturbations of the Onega-Ladoga hydrological system on the ancient coastal population. Samara Journal of Science 6, 171-177. (in Russian).

Nikonov, A.A. \& Miidel, A.M., 2003. Discovery of seismogenic deformations in the postglacial deposits at the southern coast of the Gulf of Finland. Doklady Earth Sciences 391, 641-646.

Nikonov, A.A. \& Rusakov, A.V., 2010. A unique find of a buried early Holocene paleosol on the southern coast of the Gulf of Finland: position, stratigraphy and age. Eurasian Soil Science 43, 15-23. https://doi.org/10.1134/s1064229310010035

Nikonov, A.A. \& Subetto, D.A., 2007. Historical tsunami in Solovetsky islands. Transactions of Russian Geographical Society 6, 24-31. (in Russian).

Nikonov, A.A. \& Zykov, D.S., 2017. Traces of strong earthquakes in western sector of the Murmansk zone (Karpinsky Line). Kola Scientific Centre, Transactions of the Fersman's scientific session of the Geological Institute 14, 143-147. (in Russian).

Nikonov, A.A., Belousov, T.P., Denisova, E.A., Zykov, D.S. \& Sergeev, A.P., 2001. Deformational structures in lateglacial deposits of the Karelian Isthmus: morphology, kinematics, origin. In: Tectonics of Neogea: general and regional aspects. Proceedings of the XXXIV Tectonic conference, Moscow. GEOS 2, 83-86. (in Russian).

Nikonov, A.A., Rusakov, A.V., Korkka, M.A. \& Spiridonova, E.A., 2005. A finding of early Holocene relict soil on the southern coast of the Gulf of Finland and its paleogeographic implications. Doklady Earth Sciences 403, 794-798.

Nikonov, A.A., Shvarev, S.V., Sim, L.A., Rodkin, M.V., Biske, Yu.S. \& Marinin, A.V., 2011. Seismotectonics, seismodeformations and paleo-earthquakes in the key-area "Inostrantsev Caves": the experience of detailed investigations on the Fennoscandian shield. In: Proceedings of the Russia Conference "Problems of seismotectonics", Moscow. 384-388. (in Russian).

Nikonov, A.A., Shvarev, S.V., Sim, L.A., Rodkin, M.V., Biske, Yu.S. \& Marinin, A.V., 2014. Paleoseismodeformations of hard rocks in the Karelian isthmus. Doklady Earth Sciences 457, 1008-1013. https://doi.org/10.1134/s1028334x14080145

Ojala, V. J., Kuivamäki, A. \& Vuorela, P., 2004. Postglacial deformation of bedrock in Finland. Geological Survey of Finland, Nuclear Waste Disposal Research. Report YST-120, 23 p.

Olesen, O., Henkel, H., Lile, O.B., Mauring, E. \& Ronning, J.S., 1992. Geophysical investigations of the Stuoragurra postglacial fault, Finnmark, Northern Norway. Journal of Applied Geophysics 29, 95-118. https://doi.org/10.1016/0926-9851(92)90001-2

Pajunen, H., 2004. Järvisedimentit kuiva-aineen ja hiilen varastona. Summary: Lake sediments as a store of dry matter and carbon. Geological Survey of Finland, Report of Investigation 160, $308 \mathrm{p}$.

Pajunen, H., 2005. Ala-Saimaan sedimentaatioympäristön muuttuminen jääkauden jälkeen (Early Holocene change in the sedimentation environment at lower Lake Saimaa). Terra 117: 1,33-46.

Remes, K-M., Tervo, T. \& Nenonen, J., 2013. Imatran geoinventointi. Geological Survey of Finland, Report $\mathrm{M} 65 \mathrm{~K} / 2013,50 \mathrm{p}$.

Saarnisto, M., 1970. The Late Weichselian and Flandrian History of the Saimaa Lake Complex. Commentationes Physico-Mathematicae, Societas Scientiarum Fennicae $37,107 \mathrm{p}$.

Saarnisto, M., 1977. Deformational structures in the first Salpausselkä end moraine, Joutsenonkangas, SouthEastern Finland. Bulletin of the Geological Society of Finland 49, 65-72. https://doi.org/10.17741/bgsf/49.1.012

Sederholm, J.J., 1897. Über eine archaische Sedimentformation im südwestlichen Finland und ihre Bedeutung für die Erklärung der Entstehungsweise des Grundgebirges. Bulletin de la Commission géologique de Finlande 6, $254 \mathrm{p}$.

Shvarev, S.V., Nikonov, A.A. \& Rusakov, A.V., 2018. Wedgeshaped structures in loose sediments of the Neva Lowland as a result of seismic effects in the early Holocene (the keyplot "Nizino"). Geomorphologija 2, 98-113. (in Russian).

Sjöberg, R., 1994. Bedrock caves and fractured rock surfaces in Sweden. Occurrence and origin. Ph.D. thesis, Paleogeophysics and Geodynamics, Stockholm University, $110 \mathrm{p}$.

Zykov, D.S., 2001. Recent geodynamics of North Karelian zone (Baltic shield). Transactions of GIN RAS, Vol. 534, Moscow: GEOS, 146 p. (in Russian). 